doc. dr. sc. Marko Čular

Ekonomski fakultet, Sveučilište u Splitu, Split, Republika Hrvatska

marko.cular@efst.hr

Petra Šupe, mag.oec.

petra.supe@gmail.com

\title{
UTJECAJ DRŽAVNE REVIZIJE NA UČINKOVITOST RADA LOKALNIH JEDINICA U HRVATSKOJ ${ }^{1}$
}

Primljen: 17. lipnja 2020.

Prihvaćen: 12. listopada 2020.

https://doi.org/10.46458/27121097.2020.26.52

\section{Prethodno priopćenje}

\section{Sažetak}

Državna revizija je neizostavan dio demokratskog sustava te predstavlja mehanizam za jačanje odgovornog, transparentnog i pouzdanog nadzora nad javnim rashodima. Državna revizija se obavlja za račun i u ime države, a državni revizori igraju ključnu ulogu kao neovisni i kompetentni stručnjaci. U Hrvatskoj, institucija koja istražuje jesu li javna sredstva upotrijebljena na učinkovit i djelotvoran način je Državni ured za reviziju. Državni ured za reviziju objavljuje strateški plan prema kojem obavlja reviziju subjekata državne revizije (jedinice državnog sektora, jedinica lokalne samouprave i uprave, pravni subjekti koji se u cijelosti financiraju iz proračuna ili su u većinskom vlasništvu države ili jedinica lokalne samouprave ili uprave). Tako je, prema strateškom planu, provedena državna revizija 75 lokalnih jedinica (20 županija i Grad Zagreb, 28 gradova, 26 općina) u 2018. godini. Predmet revizije su bili financijski izvještaji i uskladenost poslovanja, a predmet ovog rada je analiza rezultata provedbe državne revizije lokalnih jedinica. Revizijom su uočene brojne nepravilnosti i propusti na području planiranja i izvršenja proračuna, računovodstvenog poslovanja $i$ financijskog izvještavanja, prihoda i potraživanja, rashoda i obveza, javne nabave te imovine i drugih područja koje su rezultirale modificiranim mišljenjem. Rezultati istraživanja pokazuju da se revizijska mišljenja razlikuju s obzirom na vrstu lokalnih jedinica. U konačnici, rezultati su pokazali da državna revizija

1 Rad je rezultat diplomskog rada Petre Šupe, mag.oec., pod mentorstvom doc.dr.sc. Marka Čulara, iz kojeg su pojedini dijelovi preuzeti. 
utječe na poslovanje lokalnih jedinica, na njihovu transparentnost i učinkovitost, s obzirom na to da lokalne jedinice provedu date preporuke državnih revizora iz prethodnih razdoblja.

Ključne riječi: državna revizija, lokalne jedinice, mišljenje revizora;

JEL: M42, M48

\section{UVOD}

Državna revizija podrazumijeva postupak ispitivanja i ocjenjivanja financijskih izvještaja i transakcija jedinica državnog sektora, jedinica lokalne samouprave i uprave, pravnih subjekata koji se u cijelosti financiraju iz proračuna ili su u većinskom vlasništvu države ili jedinica lokalne samouprave ili uprave (Krasić i Žager, 2009., 65). Državna revizija obavlja se u ime i za račun države, a u Hrvatskoj je obavlja Državni ured za reviziju (vrhovna revizijska institucija u Hrvatskoj) kojom rukovodi glavni državni revizor kojeg imenuje Sabor. Podrazumijeva se da je Državni ured za reviziju eksterna, stručna i neovisna organizacija (Tušek i Žager, 2007., 76).

Državna revizija provodi se u skladu s utvrđenim revizijskim standardima Međunarodne organizacije vrhovnih revizijskih institucija (INTOSAI standardi) i Kodeksom profesionalne etike državnih revizora (Krasić i Žager, 2009., 65). Okvir Međunarodnih standarda vrhovnih revizijskih institucija sastoji se od dokumenata koje je usvojio Kongres Međunarodne organizacije vrhovnih revizijskih institucija s ciljem reguliranja profesionalnih standarda rada vrhovnih revizijskih institucija. Prema INTOSAI standardima razlikuju se dvije vrste revizija: revizija pravilnosti, odnosno financijska revizija te revizija uspješnosti odnosno revizija učinkovitosti (Vašiček et al., 2016., 27).

Značaj postojanja i rada vrhovnih revizijskih institucija još uvijek nije prepoznat, a jedan od razloga je problem njihove nedostatne komunikacije sa širom javnošću, koji se pokušava otkloniti. Shodno tome, nije dovoljno da vrhovne revizijske institucije samo provedu planirane revizije i izdaju mišljenje, već je sada već široko u praksi primjenjivo da daju preporuke prema zapaženim nepravilnostima ili slabostima, a isto tako prepoznaju snage i koriste ih za poboljšanje rada. Uz izdavanje preporuka, trebale bi pratiti implementaciju istih od strane revidiranih javnih poduzeća, stoga je rad državnih revizora dinamičan i ne završava samim činom revidiranja (Vulas, 2020., 73). Uspoređujući rad vrhovnih revizijskih institucija zemalja EU, većina zemalja ne provodi reviziju regionalne vlasti, sve 
zemlje planiraju revizije na godišnjoj razini, a tek rijetke provode zasebne planove, primjenjujući kolegijalno donošenje odluka i transparentno iskazivanje rezultata. Sukladno indeksu razvijenosti zemalja EU, vrhovne revizijske institucije u Mađarskoj i Hrvatskoj su najnerazvijeniji, dok su vrhovne revizijske institucije u Sloveniji, Luksemburgu, Švedskoj i Danskoj najbolje razvijene (Vulas, 2020., $72,74)$.

Mamić Sačer et al. (2015., 219), uspoređujući rad vrhovnih revizijskih institucija Hrvatske te Bosne i Hercegovine zaključuju da se najveća pažnja posvećuje provedbi državne financijske revizije, iako se broj revizija učinkovitosti kao zasebna vrsta revizije svake godine povećava. Nadalje, ističu kako se većina pitanja reguliranja i djelovanja vrhovnih revizijskih institucija regulira na sličan način, dok su se nacionalne specifičnosti pokazale značajnim u određivanju ustroja ovih institucija. Primjena INTOSAI standarda, kao primjena najbolje prakse različitih zemalja svijeta, zasigurno doprinosi ujednačavanju načina postupanja promatranih vrhovnih revizijskih institucija u promatranim zemljama (Mamič Sačer et al., 2015., 219).

Nastavno na sve učestalije revizije učinkovitosti koje provodi Državni ured za reviziju, Mamič Sačer et al. (2016.) istražuju jesu li hrvatska javna poduzeća učinkovitija nakon implementacije preporuka revizije učinkovitosti. Primjenom metode analize omeđivanja podataka, relativni utjecaj revizije učinkovitosti na povećanje učinkovitosti javnog poduzeća je izuzetno velik samo kod jednog poduzeća, u odnosu na 28 provjera izvršenja danih preporuka Državnog ureda za reviziju (Mamič Sačer et al., 2016., 26).

Cilj ovog istraživanja je analizirati rezultate provedbe državne revizije lokalnih jedinica u Hrvatskoj koja je obavljena u 2018. godini te objavljena na mrežnim stranicama Državnog ureda za reviziju. Državna revizija je provedena kod 75 lokalnih jedinica, od toga 20 županija i Grad Zagreb, 28 gradova i 26 općina. Predmet državne revizije su godišnji financijski izvještaji i usklađenost poslovanja. Revizijom su utvrđene brojne nepravilnosti u financijskom izvještavanju i usklađenosti poslovanja lokalnih jedinica (Državni ured za reviziju, 2020.).

U ovom radu će se analizirati priroda i učestalost nepravilnosti u radu lokalnih jedinica. Također, istražit će se postoji li razlika u vrsti revizorskog mišljenja s obzirom na vrstu lokalne jedinice te utječu li rezultati državne revizije iz prethodnih razdoblja na kvalitetu poslovanja lokalnih jedinica.

Rad se sastoji od četiri poglavlja, uključujući uvod i zaključak. U sljedećem dijelu rada se ističe važnost državne revizije u revidiranju subjekata lokalnih jedinica kroz aspekt financijske revizije lokalnih jedinica, kao i revizije usklađenosti. Treće poglavlje objašnjava izbor i obilježja uzorka, korištenu metodologiju 
istraživanja te definiranje istraživačkih hipoteza. Detaljna analiza rezultata istraživanja prikazana je u četvrtom poglavlju, kroz deskriptivnu analizu te analizu testiranja hipoteza. Na kraju rada iznose se osnovni zaključci do kojih se došlo provedbom istraživanja.

\section{LOKALNE JEDINICE KAO OBVEZNICI DRŽAVNE REVIZIJE}

Državna revizija ima veliku odgovornost i moralnu obvezu pridonositi osiguranju da javni novac bude utrošen na najbolji mogući način, utvrditi učinkovitost i prikladnost postojećih kontrola, uz to pružiti razumno uvjerenje te o svemu neovisno i pravodobno izvješćivati Hrvatski sabor. Državna revizija ima vitalnu ulogu u povećanju odgovornosti svih sudionika u procesu prikupljanja, trošenja i upravljanja proračunskim, izvanproračunskim i drugim javnim sredstvima, kao i u osiguranju transparentnosti tih aktivnosti. Tako svojim djelovanjem pomaže zakonodavnoj vlasti u kontroli, a izvršnoj u izvršenju proračuna (Krasić i Žager, 2009., 69).

U skladu s odredbama Zakona o državnom uredu za reviziju, Državni ured za reviziju je obvezan revidirati lokalne jedinice. Lokalne jedinice obvezne su kod vođenja poslovnih knjiga i sastavljanja financijskih izvještaja primjenjivati proračunsko računovodstvo, prema odredbama Zakona o proračunu, Pravilnika o proračunskom računovodstvu i Računskom planu te Pravilnika o financijskom izvještavanju u proračunskom računovodstvu.

Prema Pravilniku o financijskom izvještavanju u proračunskom računovodstvu (čl. 5), lokalne jedinice za proračunsku godinu sastavljaju sljedeće financijske izvještaje: izvještaj o prihodima i rashodima, primicima i izdacima, izvještaj o rashodima prema funkcijskoj klasifikaciji, bilancu, izvještaj o promjenama u vrijednosti i obujmu imovine i obveza, izvještaj o obvezama i bilješke. Lokalne jedinice predaju financijske izvještaje instituciji ovlaštenoj za obradu podataka i Državnom uredu za reviziju do 15 . veljače tekuće za prethodnu godinu i objavljuju ih na svojim mrežnim stranicama (prema Pravilniku, čl. 24).

S obzirom na broj i teritorijalni razmještaj lokalnih jedinica, organizacijski i financijski racionalno rješenje bilo je osnivanje područnih ureda u svim županijskim središtima. Time su izbjegnuti veliki materijalni troškovi državnih revizora čiji se rad velikim dijelom odvija na terenu, kod subjekata revizije. Pozitivna strana osnivanja područnih ureda je bolji i lakši uvid u rad subjekata revizije te njegovo praćenje zbog mogućnosti stalne izravne komunikacije te života i rada na istom području, a u skladu s tim su veće i mogućnosti korištenja lokalnih 
izvora informacija i podataka lokalnih tijela vlasti (Krasić i Žager, 2009., 108). Prema tome, Državni ured za reviziju je ustrojen kao jedinstvena institucija koja ima Središnji ured u Zagrebu i 20 područnih ureda u županijskim središtima.

Predmet revizije državnih revizora su financijska revizija i revizija usklađenosti. Financijska revizija obuhvaća reviziju financijskih izvještaja i poslovanja subjekata revizije, u ovom slučaju lokalnih jedinica, te osigurava korisnicima financijskih izvještaja neovisno mišljenje Državnog ureda za reviziju da su oni pouzdani i sastavljeni u skladu s propisima (Filipović et al., 2018., 75). To se postiže tako što državni revizor izražava svoje mišljenje o tome jesu li financijski izvještaji u svakom značajnom pogledu sastavljeni u skladu s mjerodavnim okvirom financijskog izvješćivanja ili u slučaju financijskih izvještaja sastavljenih u skladu s okvirom financijskog izvješćivanja na osnovi objektivnog prikazivanja, jesu li financijski izvještaji u svakom značajnom pogledu prikazani objektivno, odnosno daju li istinitu i objektivnu sliku u skladu s tim okvirom (ISSAI 200, t. 16). Pri provođenju revizije financijskih izvještaja, opći ciljevi revizora su: a) dobiti razumno uvjerenje o tome da financijski izvještaji, promatrani u cjelini, ne sadrže značajne netočnosti, bilo uslijed prijevare ili pogreške, što revizoru omogućuje izražavanje mišljenja o tome jesu li financijski izvještaji u svakom značajnom pogledu sastavljeni u skladu s mjerodavnim okvirom financijskog izvješćivanja; i b) izvijestiti o financijskim izvještajima i iznijeti rezultate revizije, u skladu s nalazima revizora (ISSAI 200, t. 17).

Revizijom usklađenosti se daje neovisna ocjena, kojom se utvrđuje je li predmet revizije u skladu s primjenjivim mjerodavnim podlogama koje su određene kao kriteriji. Revizija usklađenosti se obavlja tako što se ocjenjuje jesu li aktivnosti, financijske transakcije i informacije u svakom bitnom pogledu u skladu s mjerodavnim podlogama kojima se subjekt revizije rukovodi u svom radu (ISSAI 400, t. 12). Mjerodavne podloge mogu obuhvaćati pravila, zakone i propise, odluke o proračunu, politike, utvrđene kodekse, dogovorene uvjete ili opća načela kojima se rukovodi dobro financijsko upravljanje $\mathrm{u}$ javnom sektoru i postupanje javnih dužnosnika. Revizija usklađenosti može biti sastavni dio kombinirane revizije koja može obuhvaćati i druge vrste revizije (Filipović et al., 2018., 85,86).

Ciljevi državne revizije lokalnih jedinica su (Državni ured za reviziju, 2020.):

- utvrditi istinitost i vjerodostojnost financijskih izvještaja,

- analizirati ostvarenje prihoda i primitaka, te izvršenje rashoda i izdataka u skladu s planom,

- provjeriti usklađenost poslovanja sa zakonima i drugim propisima,

- provjeriti i ocijeniti učinkovitost korištenja sredstava,

- provjeriti druge aktivnosti vezane uz poslovanje lokalnih jedinica. 
U konačnici, lokalne jedinice čine sve da stvore što bolje uvjete za svoje stanovništvo. Ipak, ne postoji službena formula za mjerenje učinkovitosti, efikasnosti i uspješnosti lokalnih jedinica. Mogu se jedino usporediti iznosi i informacije objavljenje u financijskim izvješćima što je predmet rada državnih revizora, kao i predmet ovog istraživanja.

\section{DEFINIRANJE UZORKA, METODOLOGIJE I HIPOTEZA}

U Republici Hrvatskoj ustrojeno je ukupno 428 općina, 127 gradova te 20 jedinica područne samouprave, odnosno županija. Za potrebe ovog istraživanja korištena su izvješća državne revizije u 2018. godini za 75 lokalnih jedinica (što obuhvaća 17,5\% populacije), od toga 20 županija i Grad Zagreb, 28 gradova i 26 općina.

U empirijskom dijelu rada upotrijebit će se statističke metode za testiranje hipoteza. Koristit će se tabelarno prikazivanje te Hi kvadrat test. Analiza je provedena u programu IBM SPSS Statistics 23, te se zaključci donose pri razini signifikantnosti od $5 \%$.

Za potrebe empirijskog dijela rada, postavljaju se sljedeće hipoteze:

H1: Nepravilnosti u poslovanju i financijskom izvještavanju lokalnih jedinica koje su rezultirale modificiranim mišljenjem revizora su učestale.

Državna revizija ukazuje na širok splet nepravilnosti u financijskom izvještavanju i poslovanju lokalnih jedinica. Za potrebe testiranja navedene hipoteze, pretpostavit će se da su nepravilnosti učestale ako su kod polovice analiziranih lokalnih jedinica uočene nepravilnosti.

H2: Postoji razlika u vrsti revizijskog mišljenja, s obzirom na vrste lokalnih jedinica (županije, gradovi, općine).

Pretpostavlja se da će postojati značajna razlika u modificiranom mišljenju ovisno o vrsti lokalne jedinice (županija, gradovi, općine).

H3: Rad državne revizije utječe na poboljšanje kvalitete rada lokalnih jedinica.

Državna revizija u svom izvješću objavljuje dio vezan uz „Provedbu preporuka i naloga“. U tom dijelu izvješća, državni revizor prati aktivnosti koje poduzima subjekt revizije u vezi s provedbom naloga i preporuka iz prethodnih revizija. Pretpostavlja se da preporuke državne revizije utječu na trajno poboljšanje kvalitete rada i transparentnost poslovanja. 


\section{REZULTATI ISTRAŽIVANJA}

\subsection{Deskriptivna analiza}

Za svaku lokalnu jedinicu obuhvaćenu revizijom, izraženo je mišljenje o financijskim izvještajima i mišljenje o usklađenosti poslovanja. Izražena su bezuvjetna, uvjetna i nepovoljna mišljenja. ${ }^{2}$

Mišljenja državnih revizora o financijskim izvještajima lokalnih jedinica su za njih 38 bezuvjetna, 35 uvjetna i dva nepovoljna. Od ukupno 75 lokalnih jedinica, pronađene su nepravilnosti kod njih 37 što čini $49 \%$ lokalnih jedinica.

Tablica 1. Nepravilnosti u financijskim izvještajima lokalnih jedinica

\begin{tabular}{|c|c|c|}
\hline Postojanje nepravilnosti & n & \% \\
\hline $\mathrm{Da}$ & 37 & 49 \\
\hline $\mathrm{Ne}$ & 38 & 51 \\
\hline Ukupno & 75 & 100 \\
\hline
\end{tabular}

Izvor: Izrada autora

Mišljenja državnih revizora o usklađenosti poslovanja su za njih 40 bezuvjetna, 34 uvjetna i jedno nepovoljno. Od ukupno 75 lokalnih jedinica, nepravilnosti postoje u usklađenosti poslovanja kod 35 lokalnih jedinica, što čini $46 \%$ od ukupnog uzorka.

Tablica 2. Nepravilnosti kod usklađenosti poslovanja lokalnih jedinica

\begin{tabular}{|c|c|c|}
\hline Postojanje nepravilnosti & n & \% \\
\hline $\mathrm{Da}$ & 35 & 46 \\
\hline $\mathrm{Ne}$ & 40 & 53 \\
\hline Ukupno & 75 & 100 \\
\hline
\end{tabular}

Izvor: Izrada autora

2 Bezuvjetno mišljenje o financijskim izvještajima izraženo je kada su financijski izvještaji u svim važnijim odrednicama sastavljeni u skladu s primjenjivim okvirom financijskog izvještavanja. Bezuvjetno mišljenje o usklađenosti poslovanja izraženo je kada je poslovanje u svim važnijim odrednicama obavljano u skladu sa zakonima i drugim propisima koji su određeni kao kriteriji. Uvjetno mišljenje o financijskim izvještajima izraženo je kada su utvrđene nepravilnosti (netočnosti), koje pojedinačno ili skupno imaju značajan, ali nemaju prožimajući učinak na financijske izvještaje. Uvjetno mišljenje o usklađenosti poslovanja izraženo je kada poslovanje u manjoj mjeri nije obavljano u skladu s propisima i unutarnjim aktima. Nepovoljno mišljenje o financijskim izvještajima izraženo je kada su utvrđene nepravilnosti (netočnosti), koje pojedinačno ili skupno imaju značajan i prožimajući učinak na financijske izvještaje. Nepovoljno mišljenje o usklađenosti poslovanja izraženo je kada poslovanje u znatnom dijelu nije obavljeno u skladu s propisima i unutarnjim aktima koji su određeni kao kriteriji. 
Revizijom su utvrđene nepravilnosti i propusti u području planiranja i izvršenja proračuna, računovodstvenog poslovanja i financijskog izvještavanja, prihoda i potraživanja, rashoda i obveza, javne nabave te imovine i drugih područja.

U području planiranja i izvršenja proračuna, devet lokalnih jedinica je dobilo uvjetno mišljenje od strane državne revizije vezano uz planiranje i izvršenje proračuna, dok kod 88\% lokalnih jedinica nisu pronađene nepravilnosti.

Tablica 3. Nepravilnosti lokalnih jedinica kod planiranja i izvršenja proračuna

\begin{tabular}{|c|c|c|}
\hline Postojanje nepravilnosti & $\mathbf{n}$ & $\mathbf{\%}$ \\
\hline $\mathrm{Da}$ & 9 & 12 \\
\hline $\mathrm{Ne}$ & 66 & 88 \\
\hline Ukupno & 75 & 100 \\
\hline
\end{tabular}

Izvor: Izrada autora

Državna revizija pronašla je sljedeće nepravilnosti u planiranju i izvršenju proračuna: proračuni nisu doneseni u skladu s propisima jer nisu uravnoteženi; proračuni nisu doneseni prema propisanim proračunskim klasifikacijama i nisu sveobuhvatni; proračuni ne sadrže višak ili manjak prihoda i primitaka iz prethodnih godina; proračuni ne sadrže vlastite i namjenske prihode i rashode proračunskih korisnika; proračunski planovi su doneseni za jednu proračunsku godinu; proračunski planovi ne sadrže ciljeve, prioritete razvoja i pokazatelje rezultata projekata; polugodišnji i godišnji izvještaji o izvršenju proračuna pojedinih lokalnih jedinica ne sadrže izvještaje o provedbi plana razvojnih programa.

U području računovodstvenog poslovanja i financijskog izvještavanja, u 38 lokalnih jedinica su pronađene nepravilnosti u računovodstvenom poslovanju i financijskom izvještavanju, što čini 51\% od ukupnog broja lokalnih jedinica.

Tablica 4. Nepravilnosti u računovodstvenom poslovanju i financijskom izvještavanju

\begin{tabular}{|c|c|c|}
\hline Postojanje nepravilnosti & $\mathbf{n}$ & $\mathbf{\%}$ \\
\hline $\mathrm{Da}$ & 38 & 51 \\
\hline $\mathrm{Ne}$ & 37 & 49 \\
\hline Ukupno & 75 & 100 \\
\hline
\end{tabular}

Izvor: Izrada autora

Državna revizija pronašla je sljedeće nepravilnosti u računovodstvenom poslovanju i financijskom izvještavanju lokalnih jedinica: nepravilnosti pronađene kod vođenja poslovnih knjiga, evidentiranja poslovnih događaja te popisa imovine i obveza; neke pomoćne knjige nisu ustrojene, ne sadrže propisane podatke ili se ne vode ažurno; blagajničko poslovanje nekih lokalnih jedinica nije uredno vođeno; određeni prihodi, rashodi i imovina nisu evidentirani na propisanim računima 
računskog plana; kod evidentiranja nekih rashoda, umjesto načela nastanka događaja, primijenjeno je načelo novčanog tijeka; popis imovine i obveza nije bio sveobuhvatan, jer dio imovine ili obveza nije popisan; za imovinu u pripremi nije provjeren i procijenjen stupanj dovršenosti; pojedine lokalne jedinice nisu popis imovine i obveza obavile do roka koji je propisan za predaju financijskih izvještaja, zbog čega ni rezultati popisa nisu obuhvaćeni u poslovnim knjigama i financijskim izvještajima za 2018. godinu.

U području prihoda i potraživanja, kod 33\% lokalnih jedinica su pronađene nepravilnosti.

Tablica 5. Nepravilnosti u prihodima i potraživanjima

\begin{tabular}{|c|c|c|}
\hline Postojanje nepravilnosti & $\mathbf{n}$ & $\mathbf{\%}$ \\
\hline $\mathrm{Da}$ & 25 & 33 \\
\hline $\mathrm{Ne}$ & 50 & 67 \\
\hline Ukupno & 75 & 100 \\
\hline
\end{tabular}

Izvor: Izrada autora

Državna revizija pronašla je sljedeće nepravilnosti u prihodima i potraživanjima lokalnih jedinica: za dospjela potraživanja mjere naplate nisu poduzimane ili mjerama naplate nisu obuhvaćene pojedine vrste potraživanja; namjenski prihodi nisu utrošeni za propisane namjene, nego za druge proračunske potrebe; neki poslovni prostori dani su na korištenje i u zakup bez provedenog javnog poziva, odnosno natječaja, ili bez obveze plaćanja zakupnine; pojedine lokalne jedinice nisu prikupljale prihode od grobnih naknada i od spomeničke rente, iako su to trebale učiniti.

U području rashoda i obveza, kod 37\% lokalnih jedinica su utvrđene nepravilnosti, dok kod 47 lokalnih jedinica ih nije bilo.

Tablica 6. Nepravilnosti u rashodima i obvezama

\begin{tabular}{|c|c|c|}
\hline Postojanje nepravilnosti & $\mathbf{n}$ & $\mathbf{\%}$ \\
\hline $\mathrm{Da}$ & 28 & 37 \\
\hline $\mathrm{Ne}$ & 47 & 63 \\
\hline Ukupno & 75 & 100 \\
\hline
\end{tabular}

Izvor: Izrada autora

Državna revizija pronašla je sljedeće nepravilnosti u rashodima i obvezama lokalnih jedinica: masa sredstava za plaće veća je od propisane; obavljanje komunalnih djelatnosti izravno je povjeravano pravnim i fizičkim osobama, bez 
provedenih postupaka javnih natječaja ili prikupljanja ponuda; neki programi održavanja i gradnje komunalne infrastrukture ne sadrže propisane elemente; lokalne jedinice nisu propisale uvjete, kriterije i procedure za dodjelu donacija; za odabir programa odnosno projekata nisu provodile javne natječaje ili s korisnicima donacija nisu zaključile ugovor; lokalne jedinice imaju iskazane značajne dospjele obveze i ukupni manjak prihoda i primitaka, a plan o načinu podmirenja obveza i pokriću manjka prihoda i primitaka nisu donijele.

U području javne nabave, pronađene su nepravilnosti kod 17 lokalnih jedinica, što se odnosi na $23 \%$ od ukupnog broja lokalnih jedinica.

Tablica 7. Nepravilnosti u javnoj nabavi

\begin{tabular}{|c|c|c|}
\hline Postojanje nepravilnosti & n & \% \\
\hline $\mathrm{Da}$ & 17 & 23 \\
\hline $\mathrm{Ne}$ & 58 & 77 \\
\hline Ukupno & 75 & 100 \\
\hline
\end{tabular}

Izvor: Izrada autora

Državna revizija otkrila je sljedeće nepravilnosti kod javne nabave lokalnih jedinica: lokalne jedinice donijele su plan nabave, ali pojedini planovi te izmjene i dopune planova nabave nisu objavljeni u Elektroničkom oglasniku javne nabave; planovi nisu cjeloviti, jer ne sadrže pojedine obvezne elemente; kod opisa predmeta nabave korišteni su nazivi iz računskog plana proračuna, zbog čega predmeti nabave nisu bili jasni i nedvojbeni; registri ugovora o javnoj nabavi i okvirnih sporazuma nisu ažurirani u propisanom roku ili ne sadrže neke obvezne elemente; nisu navedeni postupci javne nabave.

U području imovine i ostalih područja, pronađene su nepravilnosti kod 5 lokalnih jedinica, dok kod 94\% lokalnih jedinica nije bilo nepravilnosti.

Tablica 8. Nepravilnosti u imovini i ostalim područjima

\begin{tabular}{|c|c|c|}
\hline Postojanje nepravilnosti & $\mathbf{n}$ & $\mathbf{\%}$ \\
\hline $\mathrm{Da}$ & 5 & 6 \\
\hline $\mathrm{Ne}$ & 70 & 94 \\
\hline Ukupno & 75 & 100 \\
\hline
\end{tabular}

Izvor: Izrada autora

Državna revizija pronašla je sljedeće nepravilnosti u poslovanju lokalnih jedinica: u poslovnim knjigama nije evidentirana pojedina dugotrajna imovina koju lokalne jedinice koriste i koja bi trebala biti u njihovom vlasništvu (zemljište, groblja i mrtvačnice, imovina stečena podjelom s drugom lokalnom jedinicom), jer nisu riješeni imovinsko - pravni odnosi ili nisu pribavljeni podaci o vrijednosti; 
nisu poduzete aktivnosti za prijenos komunalnih vodnih građevina u vlasništvo javnih isporučitelja vodnih usluga, što je trebalo učiniti prema Zakonu o vodama; sustav unutarnjih kontrola nije zadovoljavajući, odnosno poslovni procesi nisu u cijelosti definirani unutarnjim aktima, odlukama i uputama; lokalne jedinice nisu donijele neke procedure (proceduru stvaranja ugovornih obveza, preuzimanje obveza po investicijskim projektima, procedure naplate prihoda i zaprimanja računa), a pojedine lokalne jedinice se donesenih procedura nisu pridržavale.

\subsection{Rezultati testiranja hipoteza}

Prvom hipotezom se tvrdi da su nepravilnosti u poslovanju i financijskom izvještavanju lokalnih jedinica koje su rezultirale modificiranim mišljenjem revizora učestale. Za potrebe testiranja hipoteze, u radu se smatra da su nepravilnosti učestale ako su kod preko polovice analiziranih lokalnih jedinica uočene nepravilnosti i modificirano mišljenje.

Tablica 9. Nepravilnosti lokalnih jedinica u financijskom izvještavanju

\begin{tabular}{|c|c|c|c|}
\hline $\begin{array}{c}\text { Postojanje } \\
\text { nepravilnosti }\end{array}$ & $\begin{array}{c}\text { Stvarne } \\
\text { vrijednosti }\end{array}$ & $\begin{array}{l}\text { Očekivane } \\
\text { vrijednosti }\end{array}$ & Rezidual \\
\hline $\mathrm{Da}$ & 37 & 37,5 & $-0,5$ \\
\hline $\mathrm{Ne}$ & 38 & 37,5 & 0,5 \\
\hline Ukupno & 75 & & \\
\hline \multicolumn{3}{|c|}{ Hi kvadrat test (p-vrijednost) } & 0.908 \\
\hline
\end{tabular}

Izvor: Izrada autora

Iako kod 49\% lokalnih jedinica postoje nepravilnosti, ne može se donijeti zaključak da su nepravilnosti lokalnih jedinica u financijskom izvještavanju učestale (p-vrijednost $>5 \%$ ).

Učestalost nepravilnosti će se također testirati i na razini pojedinih područja.

- Testiranjem nepravilnosti na razini pojedinih područja, zaključuje se da:

- manjina lokalnih jedinica (njih 24\%) s već utvrđenim nepravilnostima posluje s nepravilnostima na području planiranja i izvršenju proračuna;

- većina lokalnih jedinica (njih 100\%) s već utvrđenim nepravilnostima posluje s nepravilnostima na području računovodstvenog poslovanja i financijskog izvještavanja;

- većina lokalnih jedinica (njih 67\%) s već utvrđenim nepravilnostima posluje s nepravilnostima na području prihoda i potraživanja;

- većina lokalnih jedinica (njih 76\%) s već utvrđenim nepravilnostima posluje s nepravilnostima na području rashoda i obveza; 
- ne može se donijeti zaključak da manjina lokalnih jedinica s već utvrđenim nepravilnostima posluje s nepravilnostima na području javne nabave;

- manjina lokalnih jedinica (njih 13\%) s već utvrđenim nepravilnostima posluje s nepravilnostima na području imovine i ostalih nepravilnosti.

Tablica 10. Nepravilnosti lokalnih jedinica na razini pojedinih područja

\begin{tabular}{|c|c|c|c|}
\hline \multicolumn{4}{|c|}{ Nepravilnosti u planiranju i izvršenju proračuna } \\
\hline Postojanje nepravilnosti & Stvarne vrijednosti & Očekivane vrijednosti & Rezidual \\
\hline $\mathrm{Da}$ & 9 & 18,5 & $-9,5$ \\
\hline $\mathrm{Ne}$ & 28 & 18,5 & 9,5 \\
\hline \multicolumn{3}{|c|}{ Hi kvadrat test (p-vrijednost) } & $0.00178641 *$ \\
\hline \multicolumn{4}{|c|}{ Nepravilnosti u računovodstvenom poslovanju i financijskom izvještavanju } \\
\hline Postojanje nepravilnosti & Stvarne vrijednosti & Očekivane vrijednosti & Rezidual \\
\hline $\mathrm{Da}$ & 37 & 18,5 & 18,5 \\
\hline $\mathrm{Ne}$ & 0 & 18,5 & $-18,5$ \\
\hline \multicolumn{3}{|c|}{ Hi kvadrat test (p-vrijednost) } & 0 \\
\hline \multicolumn{4}{|c|}{ Nepravilnosti u području prihoda i potraživanja } \\
\hline Postojanje nepravilnosti & Stvarne vrijednosti & Očekivane vrijednosti & Rezidual \\
\hline $\mathrm{Da}$ & 25 & 18,5 & 6,5 \\
\hline $\mathrm{Ne}$ & 12 & 18,5 & $-6,5$ \\
\hline Hi kvadrat test (p-vrijedn & ost) & & $0.03257457 * *$ \\
\hline \multicolumn{4}{|c|}{ Nepravilnosti u području rashoda i obveza } \\
\hline Postojanje nepravilnosti & Stvarne vrijednosti & Očekivane vrijednosti & Rezidual \\
\hline $\mathrm{Da}$ & 28 & 18,5 & 9,5 \\
\hline $\mathrm{Ne}$ & 9 & 18,5 & $-9,5$ \\
\hline \multicolumn{3}{|c|}{ Hi kvadrat test (p-vrijednost) } & $0.00178641^{*}$ \\
\hline \multicolumn{4}{|c|}{$\begin{array}{r}\text { Nepravilnosti u području javne nabave } \\
\end{array}$} \\
\hline Postojanje nepravilnosti & Stvarne vrijednosti & Očekivane vrijednosti & Rezidual \\
\hline $\mathrm{Da}$ & 17 & 18,5 & $-1,5$ \\
\hline $\mathrm{Ne}$ & 20 & 18,5 & 1,5 \\
\hline \multicolumn{3}{|c|}{ Hi kvadrat test (p-vrijednost) } & 0.6220477 \\
\hline \multicolumn{4}{|c|}{ Nepravilnosti u području imovine i ostale nepravilnosti } \\
\hline Postojanje nepravilnosti & Stvarne vrijednosti & Očekivane vrijednosti & Rezidual \\
\hline $\mathrm{Da}$ & 5 & 18,5 & $-13,5$ \\
\hline $\mathrm{Ne}$ & 32 & 18,5 & 13,5 \\
\hline \multicolumn{3}{|c|}{ Hi kvadrat test (p-vrijednost) } & $0.00000905^{*}$ \\
\hline
\end{tabular}

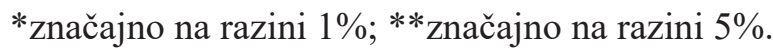

Izvor: Izrada autora 
U drugoj hipotezi utvrdit će se postoji li razlika u vrsti revizijskog mišljenja, s obzirom na vrste lokalnih jedinica (županije, gradovi, općine). Prema dolje navedenoj tablici, najveći broj uvjetnih mišljenja je utvrđen u općinama (u 80\% općina). Na temelju rezultata Hi kvadrat testa, može se donijeti zaključak da postoji statistički značajna razlika u revizijskom mišljenju, s obzirom na vrstu lokalnih jedinica (p-vrijednost je $0.2 \%$ ).

Tablica 11. Revizijska mišljenja po vrstama lokalnih jedinica

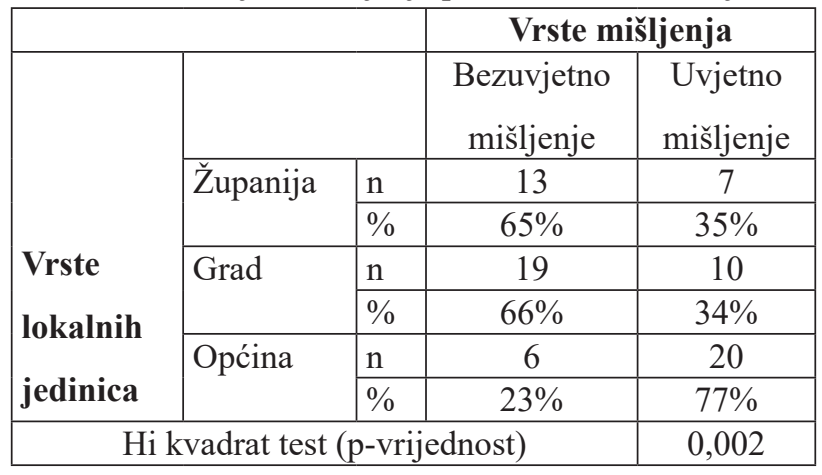

Izvor: Izrada autora

Nepravilnosti i propusti u općinama se javljaju iz više mogućih razloga. Općine su mala mjesta, stoga i imaju manji broj zaposlenika (problem je i u pronalasku kvalificiranog osoblja) te je teško uspostaviti sve potrebne odjele da bi općina funkcionirala (najčešće je uspostavljen odjel računovodstva i upravni odjel). Ključni aspekt je i taj da općine nisu obvezne ustrojiti unutarnju kontrolu kao funkciju koja je ugrađena u poslovanje, a unutarnje kontrole povećavaju vjerojatnost da će podaci u financijskim izvještajima biti točni, a sredstva korištena racionalno i učinkovito.

Trećom hipotezom se pretpostavlja da državna revizija utječe na poboljšanje kvalitete rada lokalnih jedinica. Državna revizija u svakom izvješću objavljuje dio pod nazivom „Provedba preporuka i naloga““. U tom dijelu izvješća, Državni ured za reviziju prati aktivnosti koje poduzima subjekt revizije u vezi s provedbom naloga i preporuka iz prethodnih razdoblja. Pretpostavlja se da preporuke državne revizije utječu na trajno poboljšanje kvalitete rada i transparentnost poslovanja, ukoliko lokalne jedinice provedu preko $50 \%$ naloga i preporuka državne revizije. ${ }^{3}$

3 Za utvrđene nepravilnosti i propuste, lokalnim jedinicama 2018. godine, dano je 508 naloga i 99 preporuka. Većina naloga i preporuka dana je za nepravilnosti i propuste u računovodstvenom poslovanju i financijskom izvještavanju, u području rashoda te prihoda i potraživanja. Uz navedeno, revizijom za 2018. utvrđene su i nepravilnosti koje se odnose na primjenu novih, odnosno izmjenu postojećih zakona i provedbenih propisa u područjima računovodstvenog poslovanja i ostvarivanja rashoda. Lokalnim jedinicama je u prošlim revizijama, 2017. godine, dano 610 naloga i preporuka. 
Grafikon 1. Preporuke i nalozi državne revizije

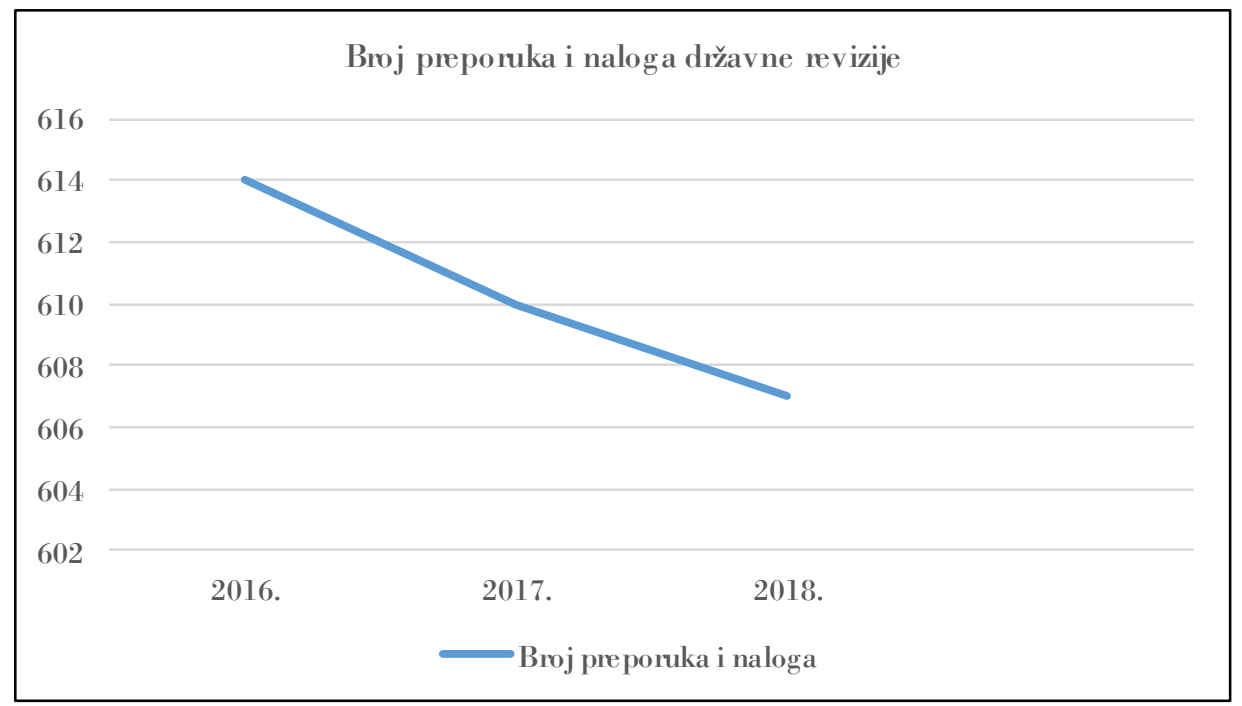

Izvor: Izrada autora

Iz grafa 1 se primijeti silazni trend preporuka i naloga državne revizije što znači da svake godine lokalne jedinice posluju s manje nepravilnosti. Iako je broj preporuka i naloga sve manji, razlike između njih nisu velike. U sljedećoj tablici i grafu slijedi prikaz koliko je preporuka i naloga provedeno.

Tablica 12. Provođenje preporuka i naloga državne revizije iz 2017. godine

\begin{tabular}{|l|c|c|c|}
\hline $\begin{array}{c}\text { Preporuke i nalozi } \\
\text { državne revizije }\end{array}$ & Stvarna vrijednost & $\begin{array}{c}\text { Očekivana } \\
\text { vrijednost }\end{array}$ & Rezidual \\
\hline Provedeno & 365 & 305 & 60 \\
\hline Neprovedeno & 245 & 305 & -60 \\
\hline \multicolumn{2}{|c|}{ Hi kvadrat test (p-vrijednost) } & 0,00000118 \\
\hline
\end{tabular}

Izvor: Izrada autora

Financijskom revizijom za 2018., utvrđeno je da je 365 ili 59,8\% naloga i preporuka provedeno, 127 ili $20,8 \%$ nije provedeno, djelomično je provedeno ili je u postupku provedbe 97 ili 15,9\% naloga i preporuka, a zbog izmjene propisa ili neprovođenja aktivnosti nije primjenjivo 21 ili 3,5\% naloga i preporuka. Većina naloga i preporuka po kojima lokalne jedinice nisu postupile odnose se na računovodstveno poslovanje, naplatu potraživanja i rashode u dijelu komunalnih djelatnosti. Lokalne jedinice su i nadalje u obvezi postupati prema nalozima i preporukama, koje nisu u cijelosti provedene.

Razina prihvaćanja preporuka od 50\% je stajalište autora, s obzirom na realno okruženje u kojem posluju lokalne jedinice te praktične primjene preporuka državnih revizora. U situaciji kada se pokaže uzlazan trend prihvaćanja preporuku u praktičnom smislu, razina prihvaćanja bi se trebala svakako povećati. 
Iz tablice 12 se može utvrditi da su lokalne jedinice provele 365 naloga i preporuka državne revizije, što je za 60 naloga i preporuka više od očekivanog. Neprovedeno je 245 naloga i preporuka što je za 60 manje od očekivanog.

Nadalje, na temelju empirijske Hi kvadrat vrijednosti, može se zaključiti da su lokalne jedinice provele statistički značajan broj naloga i preporuka lokalne revizije $(\mathrm{p}<0,05)$. Grafom 2 se također može zaključiti da iako razlike u broju preporuka i naloga iz godine u godinu nisu velike, lokalne jedinice provedu većinu preporuka što im nalaže državna revizija.

Grafikon 2. Preporuke i nalozi državne revizije

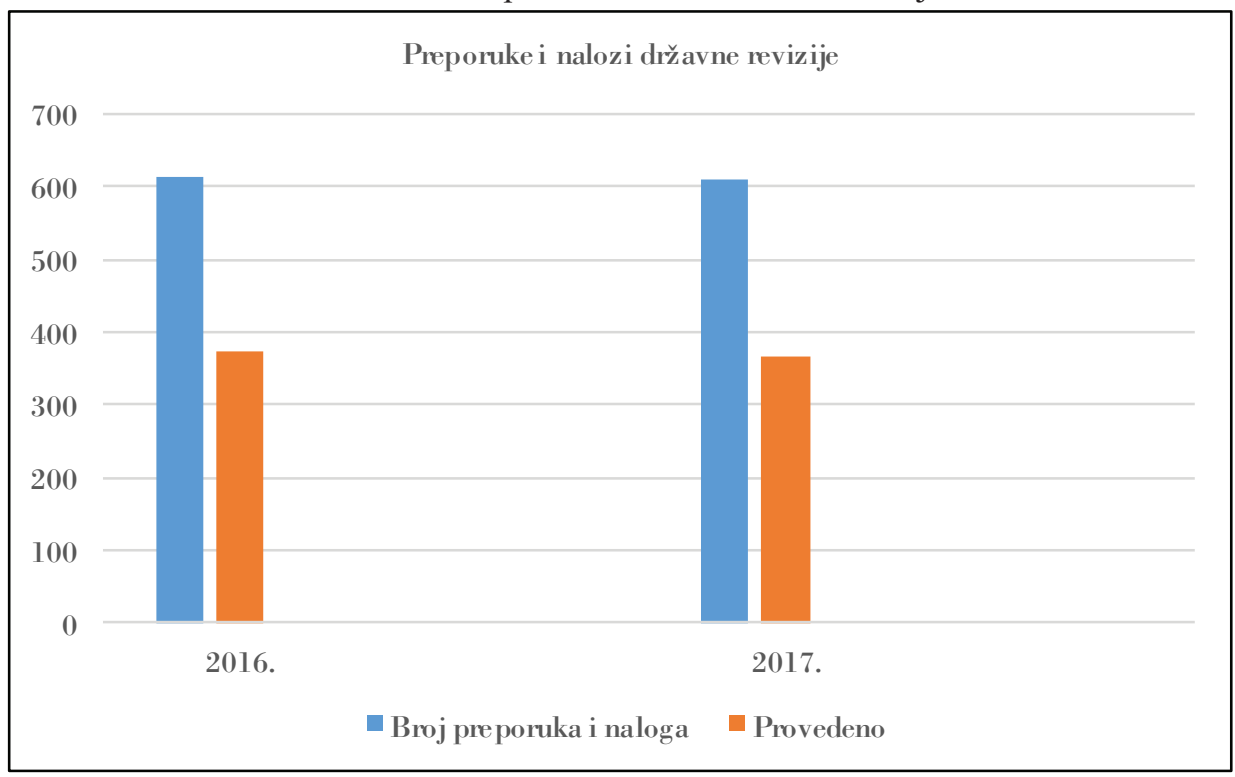

Izvor: Izrada autora

Slijedom rezultata provedenog testiranja prihvaća se treća hipoteza da državna revizija utječe na poslovanje lokalnih jedinica. Državna revizija utječe na transparentnost i učinkovitost lokalnih jedinica. Lokalne jedinice provedu u prosjeku polovicu preporuka svake godine tako da im je poslovanje svake godine efikasnije. 


\section{ZAKLJUČAK}

Državna revizija revidira subjekte koji se u većoj ili manjoj mjeri financiraju iz državnog proračuna. Glavna svrha državne revizije, koju u Hrvatskoj provodi Državni ured za reviziju, je povećanje transparentnosti subjekata i efikasnije trošenje sredstava proračuna. Državnu reviziju mogu obavljati državni revizori koji moraju biti neovisni u pružanju razumnog uvjerenja uz poštivanje kodeksa i standarda. Lokalne jedinice su samo jedni od subjekata koji su obveznici državne revizije.

Revidirano je 75 lokalnih jedinica (20 županija i Grad Zagreb, 28 gradova i 26 općina) u kojima su pronađene nepravilnosti, najviše na području računovodstvenog poslovanja i financijskog izvještavanja. Da bi se navedene i ostale nepravilnosti spriječile, državna revizija je dala posebne preporuke i naloge. Rezultati provedenog istraživanja su pokazali da su kod $49 \%$ lokalnih jedinica utvrđene nepravilnosti u poslovanju i financijskom izvještavanju lokalnih jedinica. Utvrđeno je da postoje razlike u modificiranim mišljenjima, s obzirom na vrstu lokalnih jedinica, gdje je najveći broj uvjetnih mišljenja utvrđen u općinama. Državna revizija nakon provedbe revizije daje preporuke lokalnim jedinica kako bi spriječile nepravilnosti. Testiranjem je utvrđeno da državna revizija utječe na poboljšanje poslovanja i transparentnosti lokalnih jedinica jer lokalne jedinice provedu većinu preporuka i tako smanjuju razinu nepravilnosti u svom poslovanju. Navedeni zaključak ima ograničenje, a to je pitanje odabranog uzorka lokalnih jedinica kod kojih je provedena revizija za jedno razdoblje.

Iz svega navedenog može se zaključiti da državna revizija ima značajnu ulogu u poslovanju subjekata koji se financiraju iz državnog proračuna. Također, lokalne jedinice imaju još prostora za poboljšanje svog poslovanja te bi i u budućnosti trebale provoditi što više preporuka i naloga državne revizije da bi smanjile nepravilnosti u svom poslovanju.

\section{LITERATURA}

1. Državni ured za reviziju (2018.), Izvješće o obavljenoj financijskoj reviziji lokalnih jedinica za 2017, http://www.revizija.hr/datastore/filestore/177/ IZVJESCE-O-OBAVLJENOJ-FINANCIJSKOJ-REVIZIJI-LOKALNIH-JEDINICA.pdf (pristupljeno 10.04.2020.)

2. Državni ured za reviziju (2020.), Izvješće o obavljenim revizijama, http:// www.revizija.hr/hr/ izvjesca (pristupljeno 10.04.2020.)

3. Državni ured za reviziju (2020.), Izvješće o obavljenoj financijskoj reviziji lokalnih jedinica za 2018., http://www.revizija.hr/datastore/filestore/177/ IZVJESCE-O-OBAVLJENOJ-FINANCIJSKOJ-REVIZIJI-LOKALNIH-JEDINICA.pdf (pristupljeno 10.04.2020.) 
4. Filipović, I., Bartulović, M., Filipović, M. (2018.), Revizija - mehanizam nadzora i povjerenja, Redak d.o.o., Split.

5. Hrženjak, J. (2004.), Lokalna i regionalna samouprava u Republici Hrvatskoj, Informator, Zagreb.

6. ISSAI 200, Temeljna načela financijske revizije, Državni ured za reviziju, https://www.revizija.hr/UserDocsImages/novosti/dokumenti/ISSAI_200. pdf(pristupljeno 19.10.2020.)

7. ISSAI 400, Temeljna načela revizije usklađenosti, Državni ured za reviziju, https:/www.revizija.hr/UserDocsImages/novosti/dokumenti/ISSAI_400. pdf(pristupljeno 19.10.2020.)

8. Krasić, Š., Žager, L. (2009), Državna revizija, Masmedia d.o.o., Zagreb.

9. Mamić Sačer, I., Vuković, D., Pavić, I. (2015), Komparativna analiza vrhovnih revizijskih institucija u Republici Hrvatskoj i Bosni i Hercegovini, broj XXI - posebno izdanje, str. 204-224.

10. Mamić Sačer, I., Vuković, D., Pavić, I. (2016.), Utjecaj preporuka državnih revizora na povećanje učinkovitosti javnih poduzeća, broj XXII - posebno izdanje, str. 11-28.

11. Pravilnik o proračunskom računovodstvu i računskom planu, NN 124/2014108/2020, https://narodne-novine.nn.hr/clanci/sluzbeni/2014_10_124_2374. html, (pristupljeno 21.10.2020.)

12. Pravilnik o financijskom izvještavanju u proračunskom računovodstvu, NN 03/2015-126/2019, http://www.propisi.hr/print.php?id=3204, (pristupljeno 10.04.2020.)

13. Strateški plan državnog ureda za reviziju 2020.-2022., http://www.revizija.hr/hr/o-nama/planovi-i-financijski-izvjestaji/strateski-plan (pristupljeno 10.04.2020.)

14. Tušek B., Žager, L. (2007.), Revizija - drugo, izmijenjeno i dopunjeno izdanje, Zagreb, Hrvatska zajednica računovođa i financijskih djelatnika.

15. Vašiček, V., et al. (2016.), Računovodstvo, revizija i kontrola javnog sektora u odabranim državama jugoistočne Europe, https://www.efzg.unizg.hr/ UserDocsImages/HRZZprojekti/Vasicek/Racunovodstvo\%20e-izdanje.pdf (pristupljeno 21.10.2020.)

16. Vulas, N. (2020.), Komparativna analiza vrhovnih revizorskih institucija u EU, https:/urn.nsk.hr/urn:nbn:hr:124:933406, (pristupljeno 21.10.2020.)

17. Zakon o Državnom uredu za reviziju, NN 25/2019., https://www.zakon. $\mathrm{hr} / \quad \mathrm{z} / 478 /$ Zakon-o-Dr\%C5\%BEavnom-uredu-za-reviziju,(pristupljeno 21.10.2020.)

18. Zakon o proračunu, NN 87/2008. - 15/2015., https://www.zakon.hr/z/283/ Zakon-o-prora\%C4\%8Dunu,(pristupljeno 21.10.2020.) 


\title{
Marko Čular, PhD
}

University of Split, Faculty of Economics, Business and Tourism, Split, Croatia marko.cular@efst.hr

Petra Šupe, mag.oec.

petra.supe@gmail.com

\section{STATE AUDIT OF LOCAL UNITS}

Received: July 16, 2020

Accepted: October 12, 2020

https://doi.org/10.46458/27121097.2020.26.52

Preliminary communication

\begin{abstract}
State audit is an indispensable part of the democratic system and represents a mechanism for strengthening responsible, transparent and reliable control over public expenditures. The state audit is performed for the account and on behalf of the state, and state auditors play a key role as independent and competent experts. In Croatia, the institution that investigates whether public funds have been used in an efficient and effective manner is the State Audit Office. The State Audit Office publishes a strategic plan according to which it audits state audit entities (public sector units, local self-government and administration units, legal entities that are fully financed from the budget or are majority owned by the state or local self-government or administration units). Thus, according to the strategic plan, a state audit of 75 local units (20 counties and the City of Zagreb, 28 cities, 26 municipalities) was conducted in 2018. The subject of the audit was the financial statements and compliance of operations, and the subject of this paper is the analysis of the results of the implementation of the state audit of local units. The audit identified a number of irregularities and omissions in the areas of budget planning and execution, accounting and financial reporting, revenues and receivables, expenditures and liabilities, public procurement and assets and other areas that resulted with modified opinion. The results of the research show that audit opinions differ depending on the type of local units. Ultimately, the results showed that the state audit affects the operations of local units, their transparency and productivity, given that local units implement the given recommendations of state auditors from previous periods.
\end{abstract}

Keywords: state audit, local units, auditor's opinion;

JEL: M42, M48 